\title{
IMMUNOLOGICAL STUDIES WITH A COMMERCIAL PREPARATION OF HUMAN CHORIONIC GONADOTROPIN *
}

\author{
By SHINICHI HAMASHIGE† AND EDWARD R. ARQUILLA
}

(From the Department of Pathology, University of California School of Medicine, Los Angeles, Calif.)

(Submitted for publication October 5, 1962; accepted December 20, 1962)

Immunological methods are being used to determine human chorionic gonadotropin (HCG) in urine and serum during pregnancy $(1-4)$ and also to localize it in tissues and tumors (5). The antisera used in these studies (1-5) were produced by immunizing rabbits with HCG preparations of widely varying specific activities. The $\mathrm{HCG}-\mathrm{HCG}$ antisera characterization studies that were performed primarily with agar gel immunodiffusion, or immunoelectrophoresis, or both, have demonstrated the presence of two or more antigenic components $(4,6-8)$.

Two ways of producing HCG-specific antisera have been reported. McKean (2) produced them by using a purified HCG preparation as antigen. An alternative is the adsorption of crude HCG antisera with urine or serum extracts to remove precipitins and extraneous antibodies $(3,6,7)$.

This study presents methods for the production of antibodies to HCG in rabbits and guinea pigs. The detection of HCG antibodies and HCG by hemagglutination and hemagglutination inhibition methods have been described. It has been possible to demonstrate several protein contaminants in a commercial HCG preparation by immunoelectrophoresis and electrophoresis. The adsorption of nonrelated antigenic components in the HCG antisera with normal male urine extract has been studied by immunoelectrophoresis, hemagglutination, and bioassay methods.

\section{MATERIALS AND METHODS}

Antigen preparations. The antigen used for immunization was prepared by suspending $5 \mathrm{mg}$ of $\mathrm{HCG}^{1}$ in 1

\footnotetext{
* Work supported in part by U. S. Public Health Service grant $2 \mathrm{G}-802$.

$\dagger$ Research Trainee in pathology, University of California.

1 Vitamerican lot PR360 and 90125 containing 2,570 and 2,790 IU, respectively. Vitamerican Corp., Little Falls, N. J.
}

$\mathrm{ml}$ of complete Freund's adjuvant. ${ }^{2}$ Identical concentrations of $\mathrm{HCG}^{1}$ in isotonic saline were used for booster preparations.

Antisera were produced in male and female New Zealand white rabbits weighing 2.5 to $3.0 \mathrm{~kg}$ and in guinea pigs weighing 300 to $400 \mathrm{~g}$.

Immunizing procedure. Immunizing doses were 5 and $1 \mathrm{mg}$ of antigen injected, respectively, into the toe pads of rabbits and paw pads of guinea pigs. Three weeks later, the animals were given two booster injections of antigen at 3- to 4-day intervals. The booster injection of $2 \mathrm{ml}$ for rabbits was given intravenously and intramuscularly in equally divided doses. The guinea pigs were given subcutaneous booster injection, $2.5 \mathrm{mg}$ of antigen, in the groin. Nine to 10 days after the course of booster injections, a test sample of blood was obtained from the ear vein of the rabbits and by cardiac puncture from the guinea pigs. If the test sample contained an adequate titre, blood was withdrawn from the lateral ear vein of the rabbit within 1 to 2 days. Guinea pigs with elevated HCG antibody titres were exsanguinated from the carotid artery. The rabbits were allowed a minimal recovery period of 1 month after bleeding. The usual course of two booster injections and harvesting of serum was employed for the subsequent production of rabbit HCG antibodies. By this immunization procedure, HCG antibody titres of $1 / 5,000$ or greater were consistently produced in 3 rabbits and 24 guinea pigs. All HCG antibody titres were determined by the hemagglutination method.

Processing of antisera. The collected blood was allowed to clot at room temperature for 2 to 4 hours. Antisera were separated by centrifugation and stored, frozen, in samples at $-50^{\circ} \mathrm{C}$. All sera used in hemagglutination studies were inactivated at $56^{\circ} \mathrm{C}$ for 30 minutes. The rabbit antisera were also first adsorbed with an equal volume of packed, washed, sheep erythrocytes. Antibody-rich globulin fractions were prepared by ethanol fractionation (9). The precipitated fractions were dialyzed against distilled water and lyophilized.

Neutralization of HCG activity by antisera. The presence of antibody in sera of HCG-immunized rabbits and guinea pigs was demonstrated by neutralizing the biologic effect of HCG in rats and frogs.

Rat prostate and accessory sex organ method (10). Intact, 21-day-old Long-Evans male rats weighing 40 to

2 Hyland Laboratories, Los Angeles, Calif. 
$65 \mathrm{~g}$ were given a subcutaneous $0.5-\mathrm{ml}$ injection of test material on 3 consecutive days. Each injection contained $0.1 \mathrm{ml}$ of HCG (10 IU) diluted to $0.5 \mathrm{ml}$ with saline, normal serum, or antisera. The rats were sacrificed on the fourth day, and the prostate and accessory sex organs removed by dissection and fixed in $10 \%$ formalin for 24 to 48 hours. The organs were weighed and the results expressed in grams per $100 \mathrm{~g}$ body weight.

Preliminary studies with the Long-Evans strain of rats with 1 to 5,10 , and $150 \mathrm{IU}$ of $\mathrm{HCG}$ per injection showed a sharp extinction of biologic response. This change occurred between 1 and 2 IU of HCG per injection. The extinction point, 2 IU of HCG, was therefore used to bioassay HCG.

Frog test (11). Adult male frogs (Rana pipiens) were injected with $1 \mathrm{ml}$ of the test material into the dorsal lymph sac. Cloacal smears were examined microscopically just before and 1 and 4 hours after injection of the test mixture. A positive test consisted of the presence of large numbers of spermatozoa in the smears. Test solutions contained $150 \mathrm{IU}$ of HCG $(0.03 \mathrm{ml})$ and $0.97 \mathrm{ml}$ of either saline, normal serum, or HCG antisera.

Preparation of HCG-conjugated sheep erythrocytes. Washed, packed, sheep erythrocytes $(0.1 \mathrm{ml})$ were suspended in a solution containing $1.5 \mathrm{mg}$ of HCG in 3.0 $\mathrm{ml}$ buffered saline, ${ }^{3}$ and $0.6 \mathrm{ml}$ of freshly diluted $1: 15$ bis (diazo) benzidine solution (12) was added. The suspension was shaken gently for 10 minutes at room temperature and then washed three times with barbitalbuffered saline with albumin (13). The washed, packed, HCG-conjugated cells were resuspended in $5 \mathrm{ml}$ of barbital-buffered saline with albumin (2\% suspension) and $0.05 \mathrm{ml}$ of this suspension was used for titrating antibodies to HCG.

Hemagglutination and hemagglutination inhibition methods. The hemagglutination method employed in titrating HCG antibodies has been described by Arquilla and Stavitsky (12). Hemagglutination inhibition was used for the estimation of HCG (12). With this technique, fractions of a microgram of the antigen significantly inhibit hemagglutination of HCG-conjugated cells by antiserum.

Cellulose acetate electrophoresis. Electrophoresis using cellulose acetate strips (14) was performed on the Shandon Universal electrophoresis apparatus 25484 in barbital buffer at $\mathrm{pH} 8.6$, ionic strength 0.08 for 1.5 hours at $0.4 \mathrm{ma}$ per $\mathrm{cm}$ of strip width. The $12 \times 2.5-\mathrm{cm}$ strips were impregnated with barbital buffer, blotted, and allowed to equilibrate for 1 hour before electrophoresis. A Heathkit model PS-3 was the current power supply. The samples were prepared as saturated solutions and applied as streaks with a $1-\mu 1$ micropipette. After completion of the electrophoresis, the strips were dried and stained with light green S.F., or Ponceau S and nigrosin.

${ }^{3}$ Buffered saline solution contains $0.15 \mathrm{M} \mathrm{NaCl}$ and $0.11 \mathrm{M}$ phosphate buffer, $\mathrm{pH} 7.4$.

* Consolidated Laboratories, Chicago, Ill.
Extracts of acetone powder from urine. Human urine powders from normal males, pregnant females, and castrate females were prepared by acetone precipitation (15). All powders were prepared from two or more sources and pooled. An aqueous preparation was made by mixing $1 \mathrm{~g}$ of acetone powder with $1 \mathrm{ml}$ of buffered saline, adjusting the $\mathrm{pH}$ to 7.0 to 7.4 , and further diluting with $4 \mathrm{ml}$ of buffered saline. The water-insoluble residue was discarded after centrifugation. Saturated solutions of these urine extracts were similarly prepared by using a large excess of the acetone powder. Solutions of these extracts were prepared immediately before use.

Adsorption of HCG antisera was carried out by adding $30 \mathrm{mg}$ per $\mathrm{ml}$ of finely ground, acetone-precipitated, normal, male urine powder, mixed and allowed to stand at room temperature for at least 3 hours. The antisera were obtained as clear supernatant fluids by centrifugation. Second and third adsorptions of antisera were similarly performed.

Agar gel methods. Double-diffusion studies in agar were accomplished on microscopic slides with $0.5 \%$ Ionagar no. $2^{5}$ in buffered isotonic saline at $\mathrm{pH} 7.0$ or in barbital buffer at $\mathrm{pH} 8.6$, ionic strength 0.08 .

Immunoelectrophoretic studies by the Scheidegger modification (16) were performed on the LKB ${ }^{6}$ electrophoresis apparatus $6800 \mathrm{~A}$ with Ionagar no. $2^{5}$ in barbital buffer at $\mathrm{pH} 8.6$, ionic strength 0.08 . Electrophoresis was performed at $4.5 \mathrm{ma}$ per slide for 1 to 3 hours. After electrophoresis, $1-\mathrm{mm}$ troughs were cut in the agar and filled with the appropriate antisera. All incubations for development of precipitin lines by double diffusion or immunoelectrophoresis were done at room temperature for 16 to 40 hours in a moist chamber. Slides for permanent records or photography were washed in several changes of saline, air-dried, and stained. The dehydrated slides were immersed in $1 \%$ acetic acid for 30 minutes, stained with phloxine-eosine for 1 hour, and washed in running tap water. The stained precipitin lines appeared as distinct, magenta-colored arcs on a light gray, agar gel background.

Staining solution. The solution used to stain precipitin lines obtained in the agar gel studies contained $0.5 \%$ phloxine $\mathrm{B}^{7}$ and $0.5 \%$ eosine $\mathrm{Y}^{7}$ in $95 \%$ ethanol.

\section{RESULTS}

Rat test. The presence in sera from immunized rabbits and guinea pigs of antibodies that neutralized the physiological activity of HCG was demonstrated with the rat test (Table I). The effect of $10 \mathrm{IU}$ of HCG on the weight of rat prostate and seminal vesicle was completely neutralized $(p=$ 0.0001 ) with $0.4 \mathrm{ml}$ rabbit or guinea pig $\mathrm{HCG}$ antisera. Similar results were obtained with the

5 Consolidated Laboratories, Chicago, Ill.

${ }^{6}$ LKB Instruments, Inc., Washington, D. C.

'Allied Chemical Corp., National Aniline Division. New York, N. Y. 
TABLE I

Effect of rabbit and guinea pig antisera on the biologic activity of human chorionic gonadotropin (HCG) in the rat*

\begin{tabular}{|c|c|c|c|}
\hline Test sample & $\begin{array}{l}\text { No. of } \\
\text { rats }\end{array}$ & $\begin{array}{c}\text { Mean wt, } \\
\text { prostate } \\
\text { and ac- } \\
\text { cesory sex } \\
\text { organs }\end{array}$ & $\mathrm{p}$ \\
\hline & & $\begin{array}{l}g / 100 \mathrm{~g} \\
\text { body wt }\end{array}$ & \\
\hline Saline & 9 & 0.15 & \\
\hline $\mathrm{HCG}$ & 15 & 0.25 & $<0.0001$ \\
\hline $\mathrm{HCG}+\mathrm{NRS}$ & 12 & 0.22 & $<0.0001$ \\
\hline HCG +NGPS & 6 & 0.21 & $<0.0001$ \\
\hline $\mathrm{HCG}+\mathrm{R}-\mathrm{HCG}$ & 9 & 0.14 & 0.42 \\
\hline $\mathrm{HCG}+\mathrm{GP}-\mathrm{HCG}$ & 6 & 0.13 & 0.47 \\
\hline $\mathrm{HCG}+\mathrm{R}-\mathrm{HCG}-\mathrm{L}$ & 6 & 0.14 & 0.27 \\
\hline
\end{tabular}

* Mean weight of rat prostate and accessory sex organs determined by the method of Diczfalusy (10). NRS $=$ normal rabbit serum; NGPS = normal guinea pig serum; R-HCG = rabbit HCG antiserum; GP-HCG = guinea pig HCG antiserum; and R-HCG-L = lyophilized, ethanol-precipitated, rabbit HCG gamma globulin.

gamma globulin-rich fraction of rabbit anti-HCG serum prepared by ethanol fractionation. Normal rabbit or guinea pig serum showed no effect $(\mathrm{p}=$ 0.49 ) on the biologic action of HCG in the rat.

The neutralizing ability in the antisera was titrated by mixing increasingly smaller increments of ethanol-precipitated, rabbit gamma globulin with $10 \mathrm{IU}$ of HCG and testing the effect of this mixture in the rat (Table II). The minimal amount of ethanol-precipitated, rabbit gamma globulin required to produce complete neutralization of HCG was equivalent to $0.05 \mathrm{ml}$ of antiserum which had a titre of $1 / 5,000$ by hemagglutination.

TABLE II

Neutralization of human chorionic gonadotropin $(H C G)$ in the rat by anti-HCG rabbit globulin

\begin{tabular}{|c|c|c|c|c|c|}
\hline \multirow[b]{2}{*}{ Group } & \multirow{2}{*}{$\begin{array}{l}\text { No. of } \\
\text { rats }\end{array}$} & \multicolumn{2}{|c|}{ Material injected } & \multirow{2}{*}{$\begin{array}{l}\text { Mean } \\
\text { wt, } \\
\text { prostate } \\
\text { and ac- } \\
\text { cessory } \\
\text { sex } \\
\text { organs }\end{array}$} & \multirow[b]{2}{*}{$\mathrm{p}$} \\
\hline & & HCG & C12J* & & \\
\hline & & $I U$ & $m g$ & $\begin{array}{l}g / 100 \mathrm{~g} \\
\text { body wt }\end{array}$ & \\
\hline A & 9 & $\begin{array}{c}\text { Saline } \\
\text { only }\end{array}$ & $\mathbf{0}$ & 0.15 & \\
\hline B & 15 & 10 & $\mathbf{0}$ & 0.25 & $>0.0001$ \\
\hline C & 4 & 10 & 2 & 0.16 & 0.42 \\
\hline D & 6 & 10 & 1 & 0.14 & 0.42 \\
\hline $\mathrm{E}$ & 6 & 10 & 0.5 & 0.22 & $>0.0001$ \\
\hline
\end{tabular}

* C12J =ethanol-precipitated rabbit HCG globulin. The globulin fraction at a concentration of $1 \mathrm{mg}$ per $\mathrm{ml}$ could be diluted $1: 256$ and
still agglutinate HCG cells.
The average standard deviation for the rat tests (Tables I and II) was $0.02 \mathrm{~g}$ per $100 \mathrm{~g}$ body weight with a range of standard deviations from 0.01 to $0.03 \mathrm{~g}$ per $100 \mathrm{~g}$ body weight per test group of rats.

Frog test. The presence of HCG antibodies in the serum of immunized rabbits and guinea pigs was also shown in the frog. Antisera, $0.97 \mathrm{ml}$, completely neutralized the biologic effect of 150 IU of HCG as shown by the absence of spermatozoa in cloacal smears. Normal rabbit and guinea pig sera did not interfere with the release of sperm elicited by $150 \mathrm{IU}$ of HCG.

Cross-reaction between urine extracts and rabbit antiserum to $H C G$. The hemagglutination inhibition method was used to demonstrate reactivity between urine extracts and HCG antiserum ( Ta-

TABLE III

Cross-reaction between rabbit antiserum to human chorionic gonadotropin (HCG) and human urine extracts

\begin{tabular}{ll}
\hline \multicolumn{1}{c}{ Inhibitor } & \multicolumn{1}{c}{ Titre* } \\
\hline $\begin{array}{l}\text { Barbital-buffered saline } \\
\text { with albumin }\end{array}$ & $1 / 25,000$ \\
HCG, $10 \mu \mathrm{g}$ & $1 / 100$ \\
HCG, $1 \mu \mathrm{g}$ & $1 / 800$ \\
$\begin{array}{l}\text { Pregnant female } \\
\quad \text { urine extract, saturated } \\
\begin{array}{c}\text { Normal male } \\
\text { urine extract, saturated }\end{array}\end{array}$ & $1 / 1,600$ \\
\hline
\end{tabular}

* Reaction with rabbit antiserum was indicated by inhibition of hemagglutination of sheep erythrocytes to which HCG was conjugated.

ble III). Significant inhibition of hemagglutination was shown with 10 and also with $1 \mu \mathrm{g}$ of HCG. The hemagglutination titre decreased from $1 / 25,000$ to $1 / 600$ when $1 \mu \mathrm{g}$ of HCG (about 2.5 IU) was added to the system. A similar inhibition of hemagglutination was noted with the addition of $0.05 \mathrm{ml}$ pregnant female urine extract. No significant change in hemagglutination titre was noted by addition of an equal amount of normal male urine extract. It therefore appears that normal male urine extract does not contain HCG or other cross-reacting substances in common with $\mathrm{HCG}$ preparation in sufficient quantities to inhibit the hemagglutination of HCG-conjugated cells by antisera. The results shown on Table III have been confirmed and reconfirmed with HCG antisera from two other rabbits. 


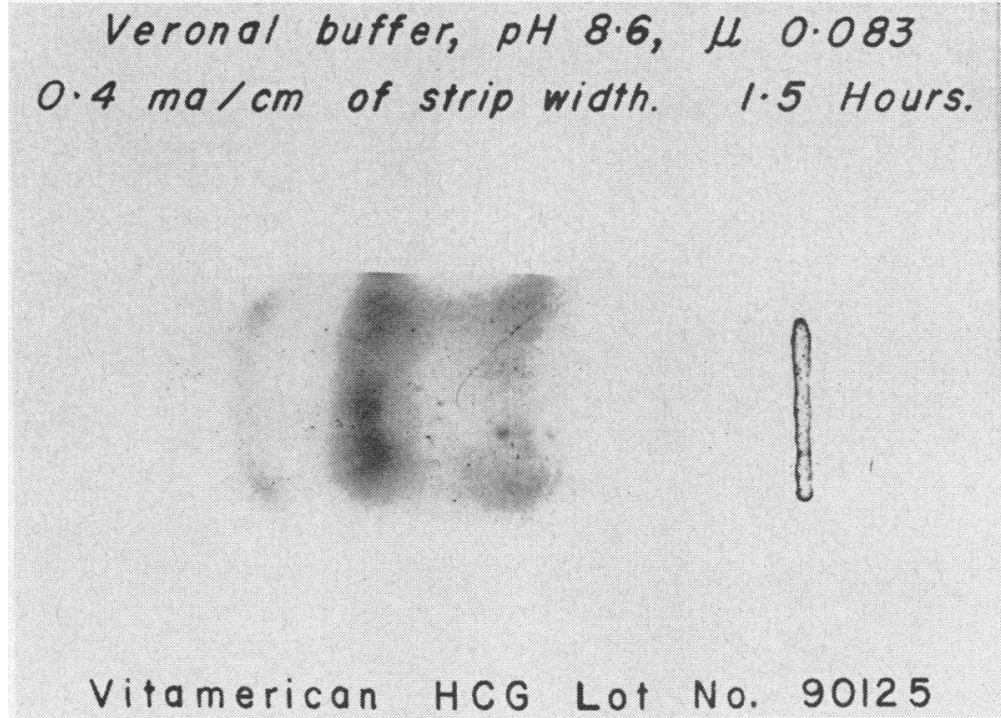

Fig. 1. Cellulose acetate electrophoresis of human chorionic GONADOTROPIN (HCG). Veronal = barbital.

Cellulose acetate electrophoretic studies. Preliminary electrophoretic studies of HCG preparations were performed on Beckman filter paper strips no. 320046 or 300028 in the Beckman Durrum cell with various buffers. The results were unsatisfactory. A single, continuous, broad, protein zone overlaid the origin and migrated toward both the cathode and anode.

Subsequently, electrophoresis of HCG was tried with cellulose acetate membrane and the result is shown on Figure 1. Three definite bands migrating toward the cathode were consistently observed. Protein-staining zones were not seen on the anode side of the origin. Nigrosin staining of electrophoretic strips can detect as little at 2 $\mu \mathrm{g}$ protein (14). These results indicate that the HCG preparations do not contain human serum proteins detectable by electrophoresis. This study also shows that Vitamerican HCG preparations contain three electrophoretically dissimilar proteins.

Cellulose acetate electrophoresis of a Squibb preparation $^{8}$ of $\mathrm{HCG}$ showed an electrophoretic pattern indistinguishable from Vitamerican HCG preparation. Electrophoresis of an Ayerst prepa-

\footnotetext{
${ }^{8}$ Follutein lot PO55561, 2,734 $\mu$ per mg generously supplied by Dr. Aleck Borman, The Squibb Institute for Medical Research, New Brunswick, N. J.
}

ration ${ }^{9}$ produced an electrophoretic pattern not unlike that seen with the acetone-precipitated urine extracts. These electrophoretic studies suggest the presence of at least three different electrophoretic protein components in HCG preparations.

\section{Immunoelectrophoretic studies}

Studies of $H C G$ with guinea pig $H C G$ antiserum. Immunoelectrophoretic studies of HCG with guinea pig HCG antiserum showed only two precipitin lines. A corollary study using HCG and rabbit HCG antiserum showed five precipitin lines. The results show that substances present in the HCG preparation produced precipitating antibodies in the rabbit, but did not produce detectable amounts of precipitating antibodies in the guinea pig. These results might be related to the number and duration of immunizations, but this problem was not investigated.

Studies of HCG with normal rabbit and rabbit anti-insulin sera. Immunoelectrophoresis of HCG with normal rabbit and rabbit anti-insulin sera showed complete absence of precipitin lines. The results suggests all precipitin lines seen with rab-

9 Ayerst APL A6996FI, generously supplied by $\mathrm{Dr}$. Daniel Michell, Jr., Harbor General Hospital, Torrance, Calif. 


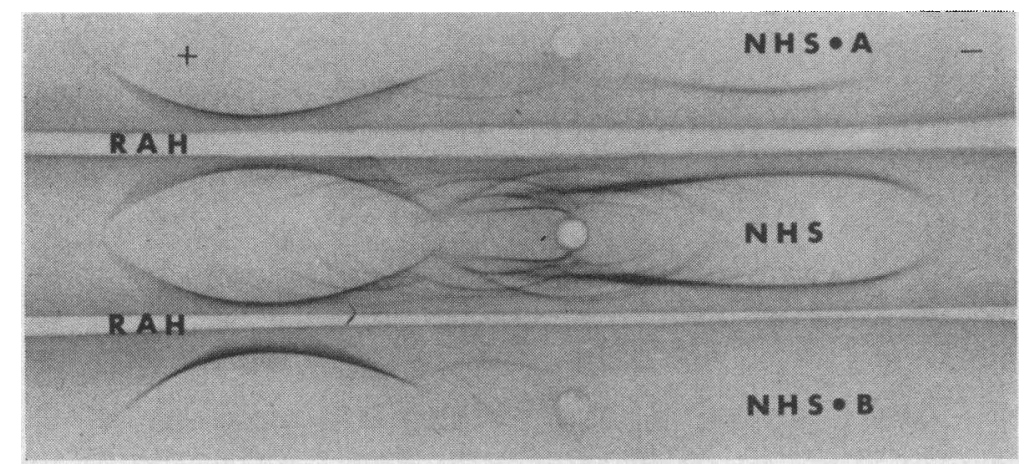

FIG. 2. IMMUNOELECTROPHORETIC STUDIES. RAH = rabbit antihuman serum; NHS = normal human serum; NHS $\cdot \mathrm{A}=$ acetone-precipitated extract of normal human serum; and NHS·B $=$ ethanol-precipitated extract of normal human serum.

bit HCG antiserum were the result of antibodies due to immunization with HCG.

Studies of human serum with rabbit anti-human serum. Normal human serum diluted with an equal volume of serum protein-free urine was precipitated with acetone (15) or alcohol (17) and studied by immunoelectrophoresis with rabbit antihuman serum. ${ }^{2}$ Serum protein-free urine, tested by immunoelectrophoretic studies, was obtained from normal young adults. The acetoneprecipitated extract of serum consistently showed more precipitin lines than the ethanol extract (Figure 2). The results indicate that acetone is less destructive to serum proteins than ethanol. The rabbit antihuman serum would detect significant amounts of unaltered serum proteins in urine extracts.

Studies of HCG and urine extracts with rabbit antihuman serum. Numerous immunoelectropho- retic studies of HCG and acetone-precipitated urine extract (Figure 3) with rabbit antihuman serum $^{2}$ were performed. All studies were completely negative for precipitin lines. The absence of serum proteins in HCG and acetone-precipitated urine extracts were strongly indicated by these studies. If present, serum proteins were in undetectably minute quantities, or else altered beyond recognition.

Study of normal male serum with rabbit HCG antiserum. In an attempt to demonstrate serum proteins in HCG preparations, immunoelectrophoretic studies of normal male serum with rabbit HCG antiserum were performed. No precipitin lines were ever observed. The negative results indicate no detectable serum protein antibodies in rabbit $H C G$ antiserum and serum proteins in the antigen preparation.

Studies of HCG with rabbit HCG antiserum.

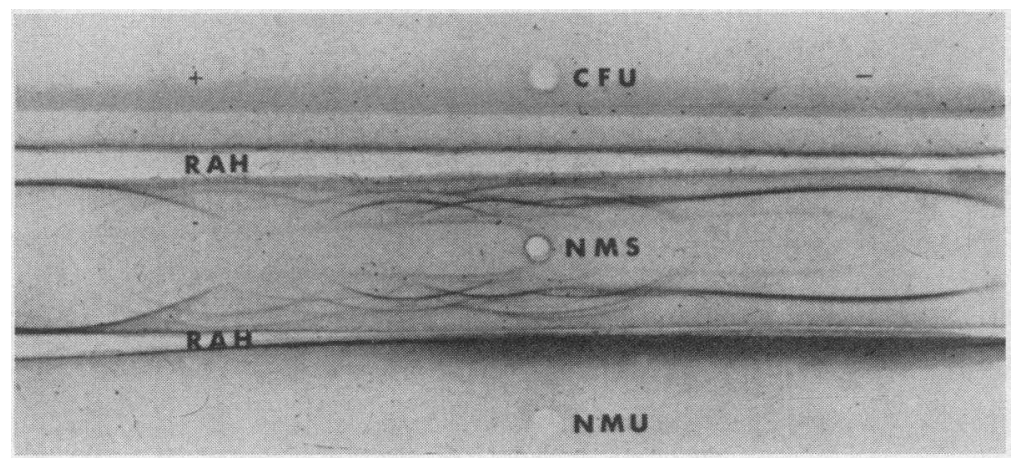

Fig. 3. IMMUNOELECTROPHORETIC STUDIES. RAH = rabbit antihuman serum ; $\mathrm{CFU}=$ castrate female urine extract $; \mathrm{NMS}=$ normal male serum ; and $\mathrm{NMU}=$ normal male urine extract. 


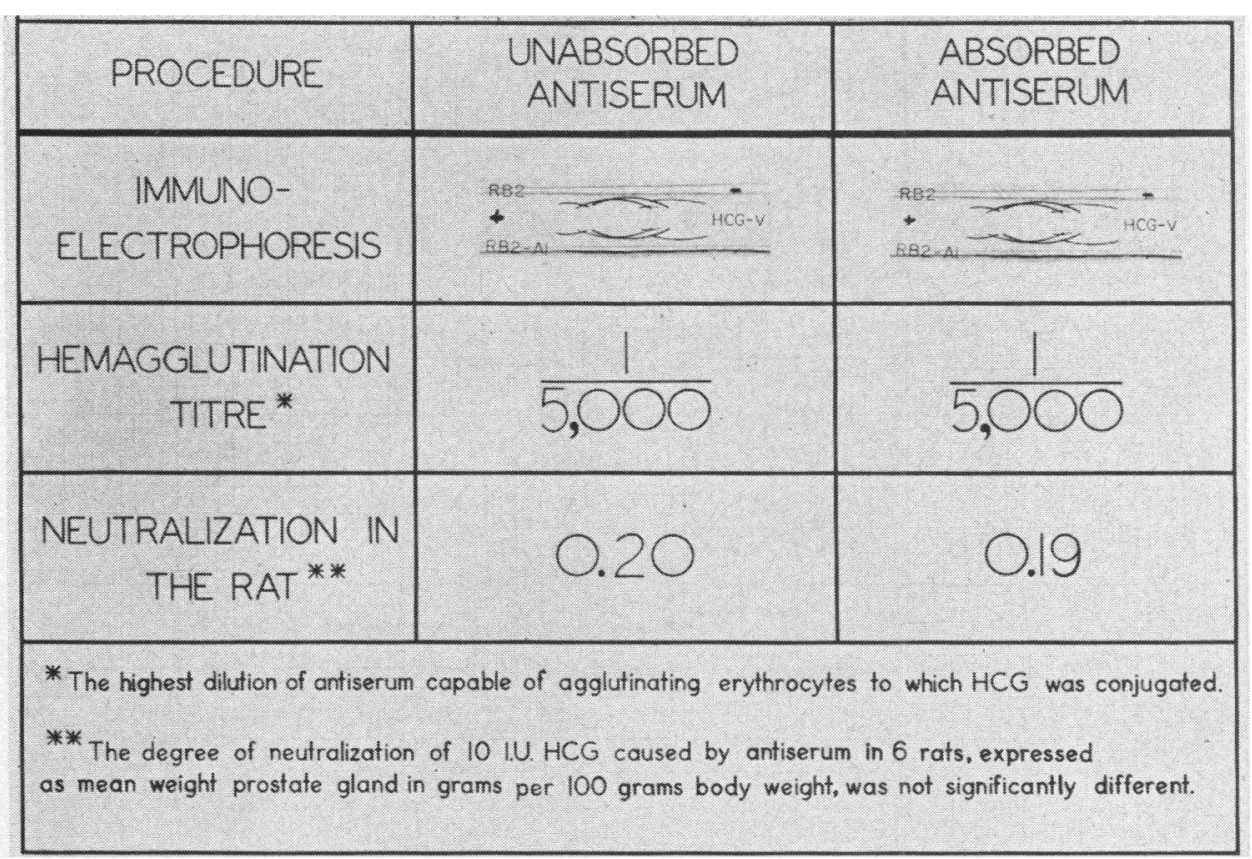

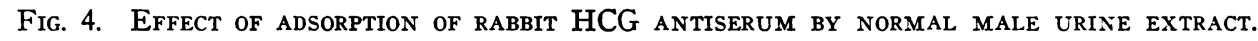

To demonstrate the number of antigenic components present in the HCG preparations, ${ }^{1,6,7} \mathrm{nu}$ merous immunoelectrophoretic studies with rabbit HCG antisera were performed. These studies showed five precipitin lines with sera from two rabbits and three, all of diminished density, from the third rabbit. Of the five precipitin lines, two were moderately dense, one was faint, and two were very faint. A photographic montage (Figure 4) composed of the immunoelectrophoretic slide with superimposed sketch is included to illustrate the precipitin lines which were not reproduced in the photographs. The two moderately dense lines were easily discernible within 24 hours of incubation; the three fainter lines were usually visible within 48 hours of incubation. Immunoelectrophoresis of Squibb and Ayerst HCG preparations with Vitamerican HCG-immunized rabbit serum showed five, two, and possibly three precipitin lines, respectively. All these precipitin lines appear to be identical with those seen with Vitamerican HCG.

This study shows Vitamerican HCG to contain a minimum of five antigenically dissimilar proteins. It also shows the presence of at least two or more common antigenic components in all three HCG preparations. With identical rabbit
HCG antiserum, the double-diffusion method in agar gel demonstrated two precipitin lines (Figure $5)$.

Studies of urine extracts with rabbit HCG antiserum. In a final effort to determine whether com-

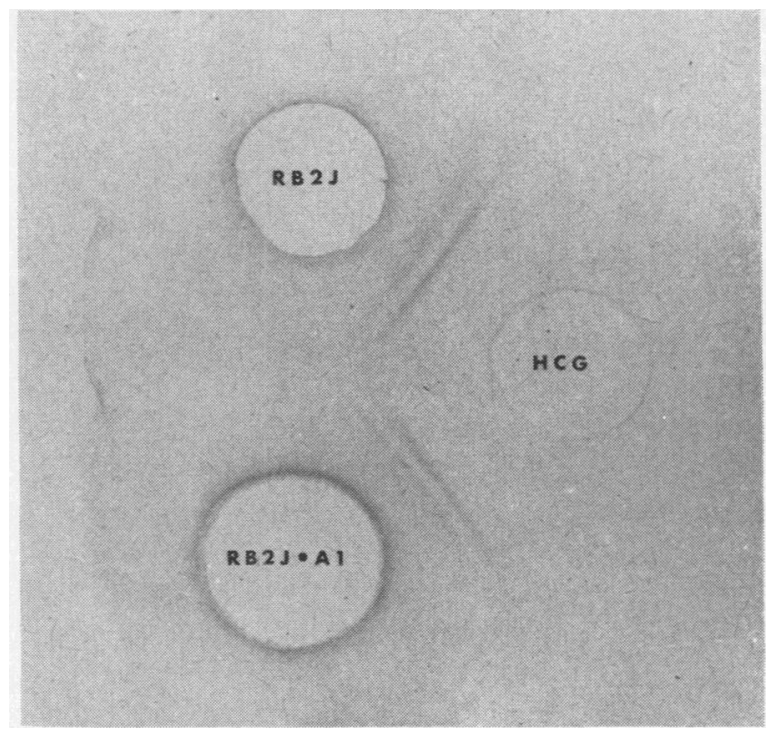

Fig. 5. Study by double-diffusion Method in AGAR GEL $\mathrm{RB} 2 \mathrm{~J}=$ rabbit $\mathrm{HCG}$ antiserum, and $\mathrm{RB} 2 \mathrm{~J} \cdot \mathrm{A} 1=$ rabbit $\mathrm{HCG}$ antiserum adsorbed once with male urine powder. 
mercial HCG preparations contain extraneous proteins, urine extracts were studied by immunoelectrophoresis with rabbit HCG antisera. A single precipitin line was noted in immunoelectrophoretic studies conducted with pregnant female, normal male, or castrate female urine extracts against rabbit $\mathrm{HCG}$ antiserum. This precipitin line appears to be dissimilar from any of those seen when HCG preparations were used as antigen against the same antiserum. This precipitin line usually required 24 or more hours of incubation to form visibly.

It appears that HCG preparations and urine extracts do not contain common antigen or antigens detectable by immunoelectrophoresis or hemagglutination. The single precipitin line seen between urine extracts and rabbit HCG antiserum was easily eliminated by one or more adsorptions of rabbit HCG antiserum with normal male urine extract.

The effect of adsorbing rabbit HCG antisera with normal male urine extract. Numerous immunoelectrophoretic studies of HCG with unadsorbed and once-adsorbed samples of identical rabbit HCG antiserum showed no discernible change in the number, relationship, rate of formation, or density of precipitin lines (Figure 4). The Ouchterlony study showed comparable results (Figure 5). Multiple adsorptions of rabbit HCG antiserum with normal male urine extract before immunoelectrophoresis decreased the number of visible precipitin lines to three. These multiple adsorptions were carried out over a day or two, and the unadsorbed sample refrigerated for a similar period also showed the disappearance of two precipitin lines. In no instance have we been able to show disappearance of one or more precipitin lines that is directly attributable to one or more adsorptions with normal male urine extract.

To study further the effect of adsorption of rabbit HCG antiserum, hemagglutination studies were performed. Unlike bioassay, hemagglutination measures a sum of immunological reactions, since the HCG and homologous antisera were previously shown to contain several antigenic components. The hemagglutination study using unadsorbed and thrice-adsorbed samples of identical rabbit HCG antiserum showed no change in titre (Table IV). The result can be resolved by concluding that 1 ) HCG is preferentially conjugated to the sheep erythrocytes and 2) multiple adsorptions with normal male urine do not remove any significant amount of antibodies from rabbit HCG antiserum. The second possibility appears much more probable. The results of the hemagglutination study have been duplicated several times.

To determine the effect of adsorption on the HCG neutralizing activity present in antiserum, thrice-adsorbed and unadsorbed samples of identical rabbit antiserum were tested in the rat. The equivalent point between HCG and HCG antiserum was used to show no loss of HCG neutralizing activity after removal of precipitins. The equivalent point was achieved, and was reflected in the organ weights of 0.19 and $0.20 \mathrm{~g}$ per $100 \mathrm{~g}$ body weight in the control and test groups; these weights are midway between HCG-positive and HCG-negative groups (Table I). The organ weights between the test and control groups show no significant difference $(p=0.45)$, indicating that the removal of precipitating antibody with normal male urine extracts had no effect on the HCG-neutralizing activity.

These adsorption studies of HCG antisera with normal male urine extract indicate no significant increased specificity for HCG. The disappearance of precipitin lines seen with adsorbed antiserum was also seen with an identical sample of unadsorbed antiserum that was refrigerated at $4^{\circ} \mathrm{C}$ for a similar period. Antisera frozen and stored at $-50^{\circ} \mathrm{C}$ did not show this loss of precipitating antibodies. We have shown that the precipitation seen with normal male urine extract added to rabbit HCG antiserum is not related to HCG.

\section{DISCUSSION}

In this study, HCG antibodies have been produced in two experimental species, and demonstrated biologically by neutralization of the physiologic activity of HCG, by hemagglutination, and by precipitation studies in agar gel. The sensitivity of the hemagglutination method used in this study is of the order of $0.5 \mu \mathrm{g}$ or 1.2 IU of Vitamerican HCG. For measuring HCG, it is therefore at least as sensitive as bioassay methods.

The formation of a precipitate between rabbit HCG antiserum and urine extracts shown by immunoelectrophoresis required that all precipitation methods for identification or assay of urinary 
HCG be performed with adsorbed HCG antiserum. Several investigators $(3,6,18)$ have previously stated this necessity. We have demonstrated the independence between HCG-neutralizing activity and precipitins removed with urine extract, confirming the work of Van Den Ende (19). This independence enables adsorption of HCG antiserum without significant impairment of HCG antibody activity.

The purity of Vitamerican HCG preparation has been studied by cellulose acetate membrane electrophoresis (Figure 1) and agar gel immunoelectrophoresis (Figure 4). These studies showed at least three and five protein components by electrophoresis and immunoelectrophoresis, respectively. The antiserum produced by immunization with HCG is, therefore, a mixture of antibodies directed toward several dissimilar proteins.

It was possible to show consistently three electrophoretic and five immunologic components in Vitamerican HCG, but we were unable to show more than two components by the Ouchterlony method (Figure 5), despite adjustments in concentration of reactants and changes in buffers. Comparative studies using identical samples of antigen and rabbit HCG antiserum by immunoelectrophoresis (Figure 4) and immunodiffusion (Figure 5) showed a difference of three precipitin lines between the two methods. Similar discrepancies have been reported by others $(4,6)$. Therefore, the proof of immunological unity or number of antigen-antibody systems present solely from studies by the Ouchterlony method appears to be incomplete.

The HCG preparation used in this study contains aproximately 2,500 IU per mg and is roughly one-fifth as pure as that of Got, Levy, and Bourrillon (20) of $12,000 \mathrm{IU}$ per $\mathrm{mg}$. Therefore, approximately $80 \%$ of the preparation represents contaminants. Various investigators have reported these contaminants to be serum and urinary proteins $(3,6-8)$. We have searched for serum proteins in the HCG preparation, using cellulose acetate membrane electrophoresis and numerous immunoelectrophoretic studies without success. Our studies indicate an absence of serum proteins in Vitamerican HCG preparation; if present, they are altered beyond recognition or are in undetectable quantities.

The presence of a "urinary protein" has been demonstrated by immunoelectrophoresis of urine extracts with rabbit HCG antiserum. We were unable to demonstrate this "urinary protein" in human serum or in our HCG preparation by immunoelectrophoretic studies. We therefore postulate that this "urinary protein" is highly antigenic and is present in HCG preparation in insufficient quantity to form visible precipitin lines. It appears to be the sole antigen or cross-reacting substance shared by the HCG preparation and acetone-precipitated urine extract. The antibody to this protein can be easily removed from antisera by adsorption with normal male urine extract.

It was not possible to demonstrate any common antigens between Vitamerican HCG and human serum or human urine extracts. This deficiency suggests that the specificity of HCG antiserum cannot be increased by adsorption with human serum or urine extracts. Studies were conducted with antiserum adsorbed 1,2, and 3 times. Samples of identical but unadsorbed, HCG antiserum were kept in the refrigerator to be used as controls for each immunoelectrophoretic run. If normal male urine extract adsorptions of rabbit HCG antiserum were to remove the precipitating antibodies to protein contaminants, then the immunoelectrophoretic study of HCG with adsorbed and unadsorbed samples of identical rabbit HCG antiserum would be expected to show a difference in the number of precipitin lines. This was not the case. In every instance, the number of precipitin lines between the central well containing HCG and the troughs on each side of the well, containing adsorbed or unadsorbed samples of identical rabbit HCG antiserum, showed an equal number of precipitin lines. The precipitin lines formed by reaction between the HCG and adsorbed HCG antiserum were sometimes of slightly diminished intensity, but not consistently so. Immunoelectrophoretic studies with adsorbed or unadsorbed rabbit HCG antiserum that were less than 12 hours old showed five precipitin lines (Figure 4). Adsorbed and unadsorbed rabbit HCG antisera stored in the refrigerator for 24 hours or more show only three precipitin lines. These studies indicate no disappearance of precipitin lines directly attributable to adsorption with normal male urine extract. It also appears that the limits of the particular antigen-antibody reaction have been reached, and factors such as 
age of antisera and addition of extraneous material could easily cause lines to disappear, and so lead to false "purification" of antisera.

To study further the effect of normal male urine extract adsorption on rabbit HCG antiserum, hemagglutination titrations were performed with adsorbed and unadsorbed samples of identical antiserum. Unlike the bioassay method, the hemagglutination method measures a sum of immunological reactions, since the HCG and its homologous antisera have been shown to contain several protein components.

The HCG conjugated to sheep red cells with bis(diazo) benzidine is a mixture of proteins, and it is not unreasonable to expect all protein moieties to be attached to the red cells to a greater or lesser degree. In the HCG hemagglutination titration, the HCG-conjugated cells are mixed with the HCG antiserum and the result is a summation of several antigen-antibody reactions. If normal male urine extract adsorption removes all antibodies except HCG-specific antibody or antibodies, a change in hemagglutination titre is expected. Our study of thrice-adsorbed rabbit HCG antiserum shows no change in hemagglutination titre, which suggests no significant removal of antibodies from the antiserum (Figure 4). This result is consistent with the immunoelectrophoretic studies. The results from the immunoelectrophoretic and hemagglutination studies indicate that HCG antiserum with multiple protein antibodies cannot be made HCG-specific by adsorption with normal male urine extract. The production of HCG-specific antiserum is probably dependent upon use of pure HCG as an antigen.

\section{SUM MARY}

1) With partially purified, commercial, human chorionic gonadotropin (HCG) as an antigen, antiHCG antibodies have been consistently produced in rabbits and guinea pigs. 2) The antibody has been demonstrated immunologically by hemagglutination and by neutralization of the biological activity of HCG in both the frog and rat. 3) An immunological method for the detection of human chorionic gonadotropin by hemagglutination inhibition has been described. 4) Electrophoretic and immunoelectrophoretic characteriza- tion of $\mathrm{HCG}$ preparations have been performed and the presence of contaminants has been demonstrated. 5) The effect of adsorbing rabbit HCG antiserum with urine extract indicates that it is not possible to make such antisera specific for HCG.

\section{REFERENCES}

1. Wide, L., and C. A. Gemzell. An immunological pregnancy test. Acta Endocr. (Kbh.) 1960, 35, 261.

2. McKean, C. M. Preparation and use of antisera to human chorionic gonadotrophin. Amer. J. Obstet. Gynec. 1960, 80, 596.

3. Brody, S. and G. Carlström. Immuno-assay of human chorionic gonadotropin in normal and pathologic pregnancy. J. clin. Endocr. 1962, 22, 564.

4. Keele, D. K., J. Remple, J. Bean, and J. Webster. Immunologic reactions to human chorionic gonadotropin. J. clin. Endocr. 1962, 22, 287.

5. Midgley, A. R., Jr., and G. B. Pierce, Jr. Immunohistochemical localization of human chorionic gonadotropin. J. exp. Med. 1962, 115, 289.

6. Midgley, A. R., Jr., G. B. Pierce, Jr., and W. O. Weigle. Immunobiological identification of human chorionic gonadotropin. Proc. Soc. exp. Biol. (N. Y.) 1961, 108, 85.

7. Rao, S. S., and S. K. Shahani. The antigenicity of human chorionic gonadotrophin. Immunology 1961, 4, 1.

8. Lunenfeld, B., C. Isersky, and M. C. Shelesnyak. Immunologic studies on gonadotropins. I. Immunogenic properties and immunologic characterization of human chorionic gonadotropin preparations (HCG) and their homologous antisera. J. clin. Endocr. 1962, 22, 555.

9. Nichol, J. C., and H. F. Deutsch. Biophysical studies of blood plasma proteins. VII. Separation of $\gamma$-globulin from the sera of various animals. J. Amer. chem. Soc. 1948, 70, 80.

10. Diczfalusy, E. An improved method for the bioassay of chorionic gonadotrophin. Acta Endocr. (Kbh.) 1954, 17, 58.

11. Robbins, S. L., and F. Parker, Jr. The use of the male North American frog (Rana pipiens) in the diagnosis of pregnancy. Endocrinology 1948, 42, 237.

12. Arquilla, E. R., and A. B. Stavitsky. The production and identification of antibodies to insulin and their use in assaying insulin. J. clin. Invest. 1956, 35, 458.

13. Kabat, E. A., and M. M. Mayer. Experimental Immunochemistry, 2nd Ed. Springfield, I1l., Charles C Thomas, 1961.

14. Chromatographic and Electrophoretic Techniques, Zone Electrophoresis, Ivor Smith, Ed. New York, Interscience, 1960, vol. 2, 
15. Frank, R. T., U. J. Salmon, and R. Friedman. Determination of luteinizing and follicle-stimulating principles in castrate and menopause urine. Proc. Soc. exp. Biol. (N. Y.) 1935, 32, 1666.

16. Scheidegger, J. J. Une micro-méthode de l'immunoélectrophorèse. Int. Arch. Allergy 1955, 7, 103.

17. Heller, C. G., and E. J. Heller. Gonadotrophic hormone: clinical application of extraction methods for assay purposes. Endocrinology 1939, 24, 319.
18. Schuyler, L. H., K. Anderson, S. Saslaw, and C. C. Erickson. A serologic study of chorionic gonadotrophin. Proc. Soc. exp. Biol. (N. Y.) 1950, 75, 552.

19. Van Den Ende, M. Precipitins in anti-gonadotrophic sera. Endocrinology 1939, 1, 156.

20. Got, R., G. Levy, and R. Bourrillon. Analyse immunoélectrophorétique de la gonadotropine choriale humaine. Experientia (Basel) 1959, 15, 480. 